Portland State University

PDXScholar

$11-16-2018$

\title{
Socializing Public Space: Benches in the Urban Setting
}

Kelsey I. Sagrero

Portland State University

Follow this and additional works at: https://pdxscholar.library.pdx.edu/honorstheses Let us know how access to this document benefits you.

\section{Recommended Citation}

Sagrero, Kelsey I., "Socializing Public Space: Benches in the Urban Setting" (2018). University Honors Theses. Paper 643.

https://doi.org/10.15760/honors.658

This Thesis is brought to you for free and open access. It has been accepted for inclusion in University Honors Theses by an authorized administrator of PDXScholar. Please contact us if we can make this document more accessible: pdxscholar@pdx.edu. 
Socializing Public Space:

Benches in the Urban Setting

\author{
Written by: \\ Kelsey Sagrero
}

An undergraduate honors thesis submitted in partial fulfillment of the requirements for the degree of

\title{
Bachelor of Science in: \\ Architecture \\ \& \\ University Honors \\ Thesis Adviser: \\ Todd Ferry
}

Portland State University

2018 


\begin{abstract}
Outdoor public space is essential to a healthy city and society. A component of such spaces are areas for staying, where people can either watch the world go by or explicitly interact with others. However, recent bureaucratic trends target and remove seating areas, such as benches, in an attempt to remove loitering, houseless activity and crimes. This public life study tries to better understand how benches are used in the public urban setting, by observing how people interact with the design of the space itself and with one another in three different locations in downtown Portland, Oregon. It is hoped that by analyzing this behaviour, the designers of our cities can have a better understanding of how to get people to stay in these public spaces and interact with people that are "other" to themselves.
\end{abstract}

Key Words: public space, benches, staying, covert socializing, overt socializing, triangulation 


\section{CONTENTS}

Introduction 3

Public Life Study $\quad 6$

Methods

Site Descriptions

Site Observations

Design Analysis

Sociological Analysis

Discussion $\quad 19$

$\begin{array}{ll}\text { Conclusion } & 22\end{array}$

$\begin{array}{ll}\text { Bibliography } & 24\end{array}$ 


\section{INTRODUCTION}

\section{In The News}

At the beginnings of my research, I came across several news articles that suggest how benches are important tools for interaction and building a sense of community. In an Op-ed, Allison Ariel writes how San Francisco has removed it's benches from their Civic Plaza and most of the city in an attempt to deter houseless activity. She believes that " keeping people away from those places — or failing to offer any place to sit at all — has become a defining feature of too much city and town planning. Is it really the goal to make our cities feel unwelcoming?" These "tools of exclusion," as she puts it, are a threat to the fabric of our city. In an attempt to counter this, she believes residents should be more involved in making their city more welcoming and inclusive.

In some areas people have started to fight back against state regulation of public spaces. One such example is in Chester, $\mathrm{UK}^{2}$ where some street artists installed tongue-in-cheek plaques on benches. This was to protest the city official's creation of a new set of laws that residents thought were clearly targeting the houseless and the vulnerable. One such plaque reads: "This bench is reserved for the young, beautiful and affluent. If you are old, ugly or poor please sit elsewhere.” Other more organized and bureaucratic-friendly efforts such as Age Friendly NYC's collaboration with the NYC Department of Transportation created a form where people can request a bench for their neighborhood. The initial motive was to make the city streets more walkable for elderly residents who need frequent places to rest while going from place to place, but anyone is allowed to request a bench. The creator say:

[The benches] just started popping up all over the place. People love them. People use them.

\footnotetext{
${ }^{1}$ New York Times
}

${ }^{2}$ Mirror 
And there's nothing about them that makes them only for old people. It's an important way of creating a town square. Old people sit on them, young people sit on them, and sometimes old people and young people sit on them together and-God forbid-talk to each other. ${ }^{3}$

If these pieces of public furniture are as important as the news articles make them out to be they could potentially minimize polarization between beliefs by encouraging people to inhabit the same space as someone that is other than them. This idea of using benches as a tool for creating a "town square," a place to socialize, and a welcoming city is what interested me. It made me want to observe public benches to see how they may be already accomplishing this and where there is room for improvement either to their design, placement or some area overlooked by previous researchers. At the least, this info could serve as an insight into how people are socializing in a world of strangers and possibly be reflective of the city's atmosphere as a whole.

\section{Theory}

It is commonly agreed among prominent public space theorists that the most prevalent form of socializing is quite simply occupying the same space as others. Jan Gehl says, "the most widespread social activity are passive contacts, that is, simply seeing and hearing other people." ${ }^{4}$ Public space advocate, Clare Cooper Marcus, also agrees and calls this form of behaviour as covert socializing ${ }^{5}$ in which "many people of all ages come to parks merely to watch people, with no intention of conversing or meeting with them.” Overt socializing ${ }^{6}$ then is when people interact with another person by speaking or communicating with them. So it would be helpful to think of covert social behaviours as more passive and implicit and overt as a more active and explicit form of socializing.

\footnotetext{
${ }^{3}$ City Lab

${ }^{4}$ Life Between Buildings, pg 14

${ }^{5}$ People Places, pg 92

${ }^{6}$ People Places, pg 91
} 
These theorists argue that architects and urban planners alike should keep in mind several points when trying to design for overt social behaviour. Ghel argues that improved settings for necessary and optional activities in public space will lend to overt social behavior. He says that "social activities occur spontaneously, as a direct consequence of people moving about and being in the same spaces. This implies that social activities are indirectly supported when necessary and optional activities

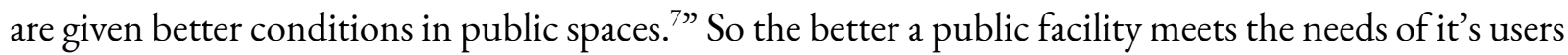
the more likely it will be to start overt social activity. This idea is supported by some of Gehl's' research that has proved that doubling seats will almost double the amount of people occupying a space. In addition to this, he thinks that flashy design is not what makes a space successful. Rather, it is the interactions in public life that make a design dynamic and interesting: "the way design is expressed is considered subordinate... Their focus is public life in interaction with design rather than design in itself." Cooper also believe the design in itself is not as important, rather the form of the public space will largely determine which of the two types of socializing people will perceive as more appropriate. She also places importance on the broader scale, suggesting that the zoning and surrounding context of the public space will determine what kind of socializing happens there. For example, she believes there will be more overt interaction in a residential area and more covert interactions in a city plaza.

Direct methods can also be used for getting people to engage in overt social behaviour. In his observations, Whyte noted that certain aspects of public life can serve as triangulation devices, by this he means the "process by which some external stimulus provides a linkage between people and prompts strangers to talk to each other as though they were not." ${ }^{\prime 9}$ He offers the examples of street performers, street art and street vendors as points of interest where strangers will be more willing to

\footnotetext{
${ }^{7}$ Life Between Buildings, pg 14

${ }^{8}$ How to Study, pg 68

${ }^{9}$ Whyte, pg 94
} 
talk with one another. In a similar way, Cooper suggests that designers should "attach benches to certain specific facilities (e.g., tennis court, tot lot, recreation building) so that one can safely assume that a fellow bench user is at the park for a similar purpose, an assumption that may offer a social opening" This suggests that designers should keep in mind existing or look for new opportunities where some aspect of the space can serve as a point of interest that will get people talking.

Another common point is people attract people. This was an idea made evident by Whyte's studies of New York City's small urban spaces. Ghel also supports this idea by stating, "new activities begin in the vicinity of events that are already in progress." ${ }^{11}$ This could be due to one of Jane Jacob's concepts that state people are more likely to feel safe in a space if there are "eyes on the street."

\section{Research Questions}

Keeping these points in mind, my research was looking for indicators of social interaction among people occupying benches - Are people sitting next to strangers on bench? Are they talking to others/starting up conversation? If not: what is getting people to talk and how can designers could build upon that? What is keeping people from interacting with one another? Design or some sociological/other factor?

\section{PUBLIC LIFE STUDY}

\section{METHODS}

For the purposes of this study, I decided to observe benches as opposed to other forms of staying (i.e. singular chair, picnic table, unconventional seating areas). This is because of their fundamental social nature - benches allow room for more than one person. Due to societal understandings of proxemics, where a person decides to sit is a visual cue to other people if they should

\footnotetext{
${ }^{10}$ Cooper, pg 92

${ }^{11}$ How to Study, pg 25
} 
be approached or not. For example, if one person were to sit in the middle of the bench, they would be communicating to others that they are dominating the bench and for others not to sit or try to share the bench with them. So in my observation journal I kept a map of where on the bench solo users stayed.

Benches are also small enough for me to conduct quality observations. Although this form of study is not taught within school of architecture, the spatial training that is acquired through such a program is enough to interpret the observations of something as small as a bench. Gehl himself says, "Naturally there is a difference between the eye of a professional and a lay person, but in principle, anyone can observe city life." ${ }^{12} \mathrm{He}$ also states that many of the great public life study pioneers "began in the realm of the personal and everyday ${ }^{13}$ " so my observations were conducted at three locations I frequent in my weekly routine.

To conduct these observations I used Gehl's recommended tools of counting, mapping, tracing and keeping a diary. ${ }^{14}$ The qualitative information gathered included counting the amount of people staying on a bench and their length of stay. I also kept a journal of my observations that I later categorized and quantified based on the activities people were doing on a bench and where they were seated on the bench. To get a more accurate scope of the activities taking place, I observed each location for two hours, three times a week, including a Friday. I also observed each location on a rainy day to see how weather affected behaviours. The locations, Couch Park, Couch Street, and Lovejoy Park, were chosen because they are all designed to have varying levels of pedestrian traffic.

${ }^{12}$ How to Study, pg 5

${ }^{13}$ How to Study, pg 58

${ }^{14}$ How to Study, pg. 24 


\section{SITE DESCRIPTIONS}

Couch St. \& 12th Ave

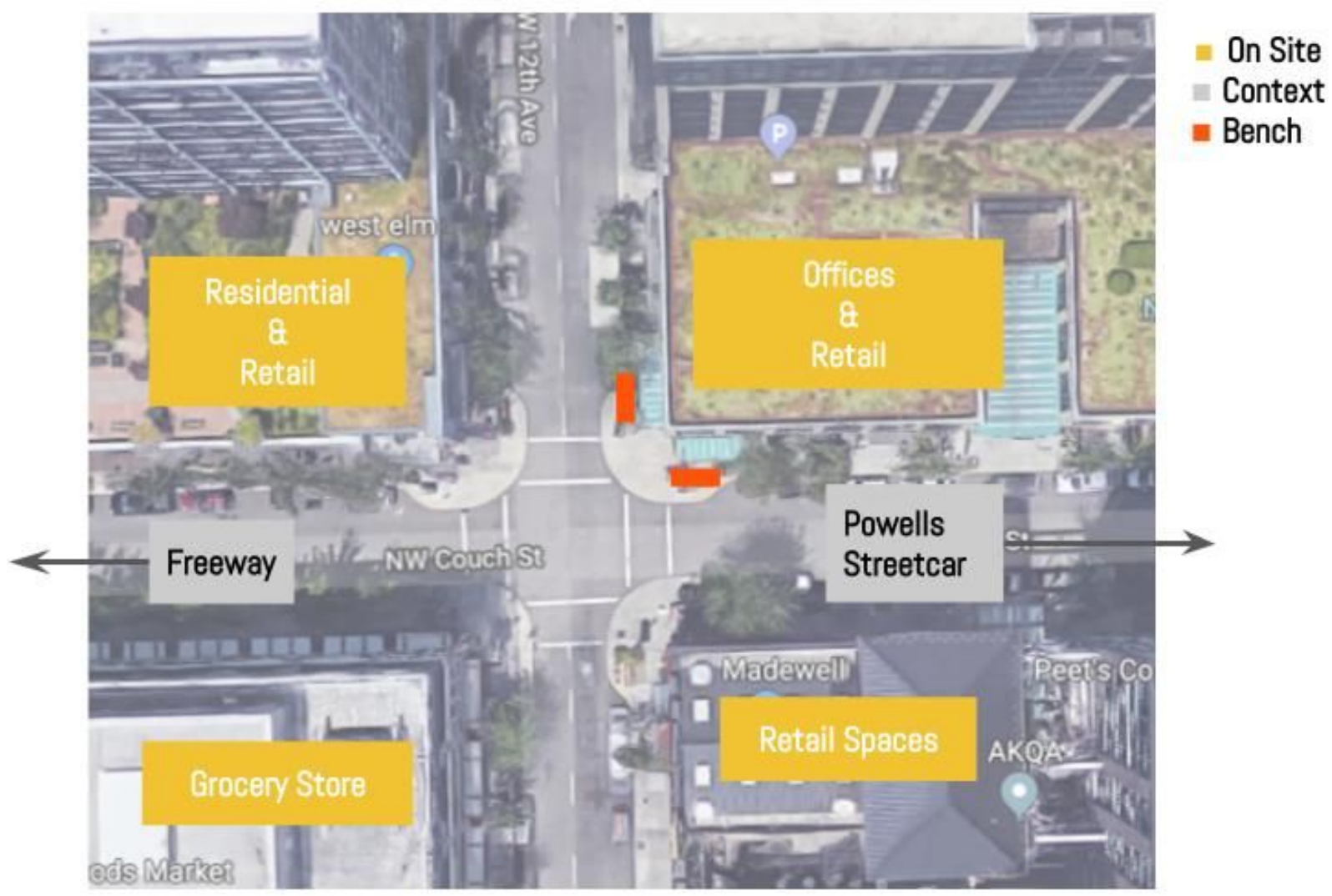

IMAGE 1. Couch Street site map; Couch Street and 12th St.

The Couch Street location is in a high density commercial, light industrial, institutional and residential zone. Surrounding it is a grocery store, various retailers and restaurants. It is located one block away from the Streetcar and Powells, so the area is frequented by tourists, locals and street performers. Although it is a highly trafficked area by cars due to its proximity to a freeway on/off ramp, curb extensions and a pedestrian scramble crosswalk make the street pedestrian friendly. The two benches observed are inset to the curb extension on the northeastern corner of 12 th and Couch. They have armrests, no dividers and are surrounded by planters, lamp posts, and a trash bin. 


\section{Couch Park}

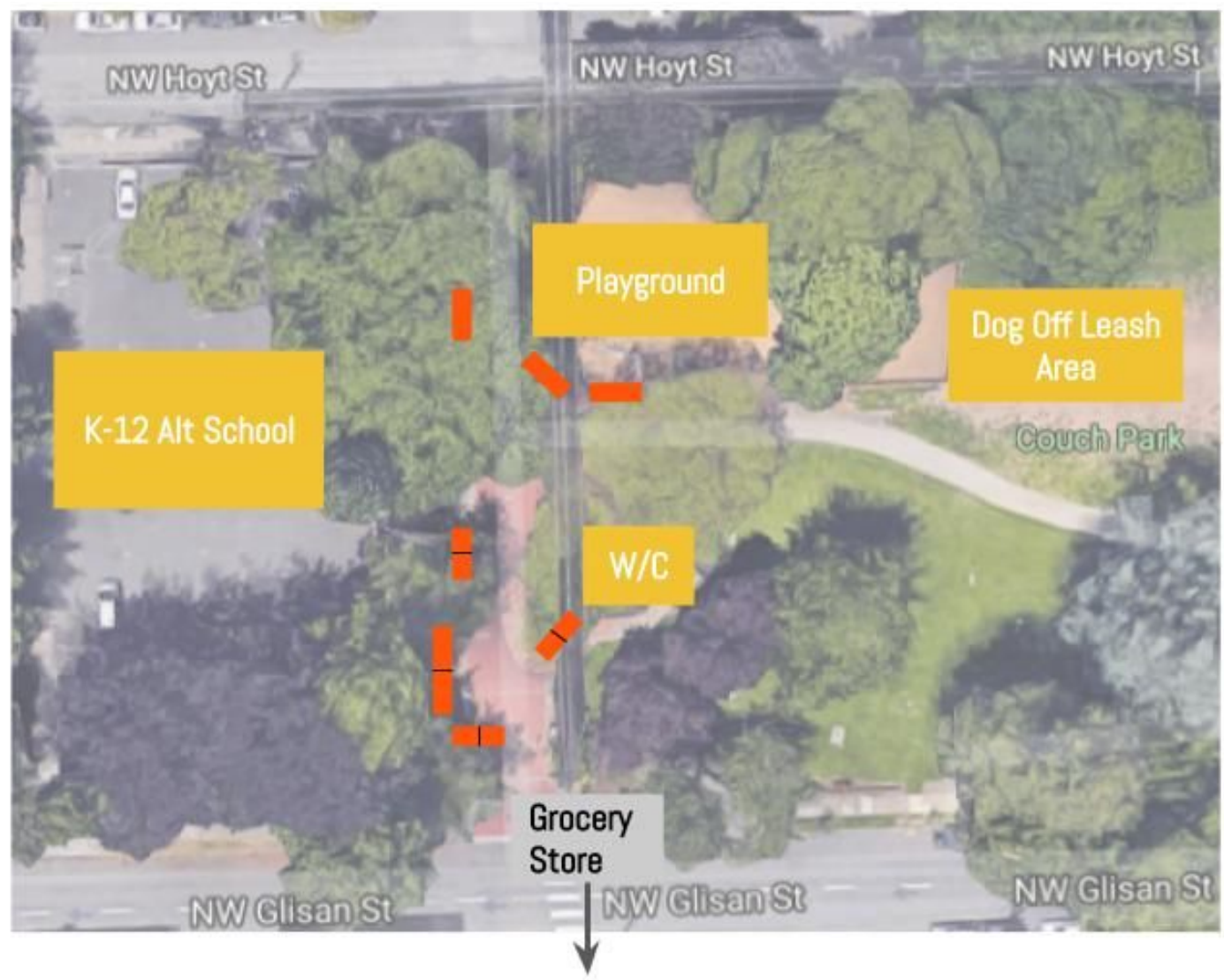

On Site

Context

- Bench

IMAGE 2. Couch Park Site Map

Couch Park is located in a high density residential and commercial mixed use zone. It is located just east of a K-12 alternative school. The park features a plaza, restrooms, playground, and a dog off-leash area. Since the park takes up two city blocks, the plaza creates a path for pedestrians to walk through the park. The seven benches that were observed are located along this path in the plaza area. Four of these benches included dividers, which are used to deter houseless from sleeping on them. The two benches closest to the playground do not have these dividers. Only one bench didn't have a back rest. The park is set to be closed and remodeled in the upcoming months. 


\section{Lovejoy Park}

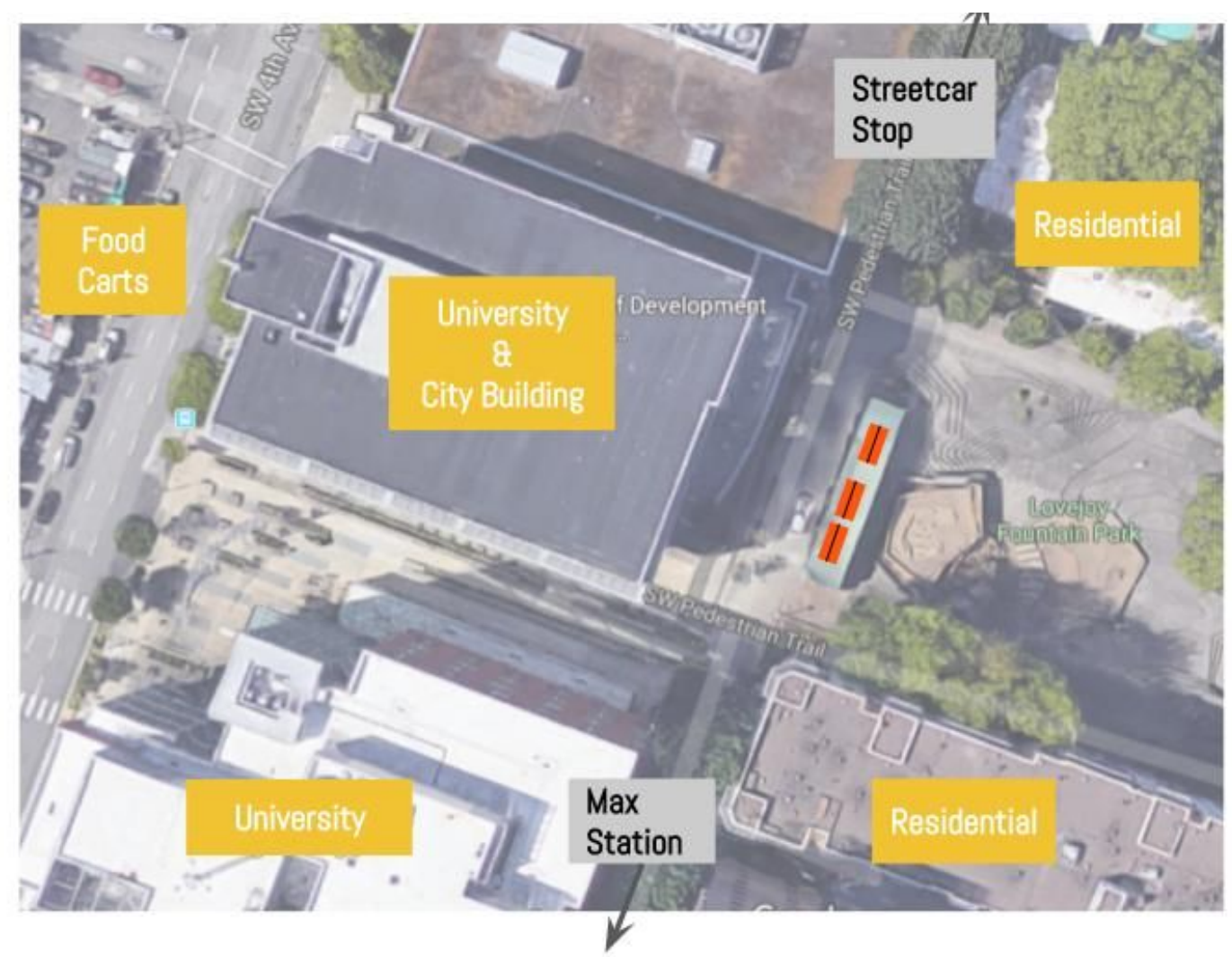

On Site

- Context

Bench

IMAGE 3. Lovejoy Park site map

Lovejoy Park is surrounded by a residential and commercial area. It is right next to the university district in downtown Portland. A series of food carts are located one block west which is frequented by university students and surrounding workers. A tram line is located one block north and south of the park. These are connected by a pedestrian pathway that runs through all of the Halprin sequence of city parks. This park specifically features a geometric fountain that was off during my observations. The 6 benches located on this site are all under a pavillion and sit back to back with one another. None of them have armrests or dividers. 


\section{SITE OBSERVATIONS}

After 18 hours of observation, there were a total of 97 parties that stayed on the benches.

Their activities and what qualifies as overt social behaviors are listed in table 1.

\begin{tabular}{|c|c|c|c|c|}
\hline & Couch Street (32) & Couch Park (43) & Lovejoy (22) & Total (97) \\
\hline \multicolumn{5}{|c|}{ Overt Activities } \\
\hline Conversing & $40.63(13)$ & $20.93(9)$ & $72.73(16)$ & $39.18(38)$ \\
\hline Greet & $9.38(3)$ & $4.65(2)$ & $9.09(2)$ & $7.22(7)$ \\
\hline Join & $21.88(7)$ & $20.93(9)$ & $54.55(12)$ & $28.87(28)$ \\
\hline PDA & $6.25(2)$ & $13.95(6)$ & $27.27(6)$ & $14.43(14)$ \\
\hline \multicolumn{5}{|c|}{ Other Activities } \\
\hline Phone & $46.88(15)$ & $41.86(18)$ & $18.18(4)$ & $38.14(37)$ \\
\hline Looking & $25.00(8)$ & $2.33(1)$ & $9.09(2)$ & $11.34(11)$ \\
\hline Eating & $18.75(6)$ & $4.65(2)$ & $9.09(2)$ & $10.31(10)$ \\
\hline Drinking & $12.50(4)$ & $13.95(6)$ & $13.64(3)$ & $13.40(13)$ \\
\hline Smoking & $50.00(16)$ & $13.95(6)$ & $22.73(5)$ & $27.84(27)$ \\
\hline Carrying & $25.00(8)$ & $37.2(16)$ & $40.91(9)$ & $34.02(33)$ \\
\hline Adjusting & $9.38(3)$ & $6.98(3)$ & $4.55(1)$ & $7.22(7)$ \\
\hline Dog & $12.50(4)$ & $4.65(2)$ & $13.64(3)$ & $9.28(9)$ \\
\hline Cleaning & $6.25(2)$ & $6.98(3)$ & $9.09(2)$ & $7.22(7)$ \\
\hline Bike & $0.00(0)$ & $9.30(4)$ & $0.00(0)$ & $4.12(4)$ \\
\hline Sleeping & $0.00(0)$ & $4.65(2)$ & $13.64(3)$ & $5.15(5)$ \\
\hline Kids & $6.25(2)$ & $34.88(15)$ & $4.55(1)$ & $49.48(18)$ \\
\hline Reading & $0.00(0)$ & $4.65(2)$ & $0.00(0)$ & $2.06(2)$ \\
\hline
\end{tabular}

TABLE 1. Total activities 


\begin{tabular}{|c|c|c|c|c|}
\hline & Couch Street (32) & Couch Park (43) & Lovejoy Park (22) & Total (97) \\
\hline \multicolumn{5}{|l|}{ Group Parties } \\
\hline $\begin{array}{l}\text { Total coming to } \\
\text { the bench with } \\
\text { others }\end{array}$ & $37.50(12)$ & $16.28(7)$ & $13.64(4)$ & $22.68(22)$ \\
\hline $\begin{array}{l}\text { Coming to the } \\
\text { bench with } \\
\text { others and no } \\
\text { overt behaviour }\end{array}$ & $3.13(1)$ & $9.30(4)$ & $0.00(0)$ & $5.15(5)$ \\
\hline \multicolumn{5}{|l|}{ Solo Parties } \\
\hline $\begin{array}{l}\text { Total coming to } \\
\text { bench solo }\end{array}$ & $62.50(20)$ & $83.72(36)$ & $86.36(18)$ & $77.32(75)$ \\
\hline $\begin{array}{l}\text { Coming to the } \\
\text { bench solo \& } \\
\text { meet others }\end{array}$ & $12.50(4)$ & $18.60(8)$ & $54.55(11)$ & $24.74(24)$ \\
\hline $\begin{array}{l}\text { Coming to the } \\
\text { bench solo \& } \\
\text { some overt } \\
\text { behaviour }\end{array}$ & $3.13(1)$ & $2.33(1)$ & $9.09(2)$ & $4.12(4)$ \\
\hline $\begin{array}{l}\text { Coming the } \\
\text { bench solo \& } \\
\text { only covert } \\
\text { behaviour }\end{array}$ & $46.88(15)$ & $62.79(27)$ & $22.73(5)$ & $48.45(47)$ \\
\hline
\end{tabular}

TABLE 2. How solo and group users socialized on benches.

Couch Park had the highest percentage of solo users followed by Couch Street and Lovejoy Park. However, most of Lovejoy Parks solo users (61.11\%) were there to meet others already at the park - this was due in part to one large group that I would consider an outlier. Although some people did come in groups, these people participated in covert social behaviour by just being in the space together but not talking to one another. 


\section{Length of stay}

\begin{tabular}{|l|l|l|l|}
\hline & Couch Park (Minutes) & $\begin{array}{l}\text { Couch Street } \\
(\text { Minutes })\end{array}$ & Lovejoy (Minutes) \\
\hline Rainy Day & 2.8 & 3.33 & 53.5 \\
\hline Sunny Day & 25.33 & 8.2 & 16.98 \\
\hline Overall & 14.07 & 5.77 & 40.39 \\
\hline
\end{tabular}

TABLE 2. Average length of stay in minutes, on benches in different locations and weathers patterns

Overall, the Couch Street benches had the shortest average stay (5.77 minutes). Lovejoy had the longest stays overall (40.39 minutes) and on rainy days (53.5 minutes). However, on sunny days, Couch Park had longer stays (25.33 minutes) than Lovejoy (16.98 minutes).

\section{DESIGN ANALYSIS}

\section{Social Function and Form}

\begin{tabular}{|l|l|l|l|l|}
\hline & Couch Street & Couch Park & Lovejoy & Total \\
\hline Overt Behavior & $50.00(16)$ & $27.91(12)$ & $77.27(17)$ & $46.39(45)$ \\
\hline $\begin{array}{l}\text { Only Covert } \\
\text { Behavior }\end{array}$ & $50.00(16)$ & $72.09(31)$ & $22.73(5)$ & $53.61(52)$ \\
\hline
\end{tabular}

Table 4. Parties participating in Covert or Overt Behaviors

Overall, there was less overt behaviour among users than covert behaviour. In the following paragraphs, I will detail what I thought was successful and unsuccessful about each design as a place for staying and ultimately covert and overt behaviour.

Couch park was successful in its design in that for the most part it met the basic necessities. As Cooper suggests in her studies, Couch Park has most of its benches backed by planters, trees, and walls to provide security. This is exemplified by the higher percentage of solo users that felt comfortable occupying the benches (65.12\%) versus Couch Street (50.01\%) and Lovejoy Park (31.82\%). By having 
the benches placed along the path, the design also encourages covert socializing behaviour by having the benches situated "so that people moving through the park... can be observed unobtrusively ${ }^{15}$," as Cooper suggests should be done to support covert behaviour.

However, I felt that Couch park could benefit from benches that encourage more interaction among strangers as most of these users (72.09\%) were just observing. As I mentioned earlier, Cooper suggest that placing benches around a similar focal point, such as a playground, indicates to others that they are there for a similar purpose and may lead to a conversation. While Couch Park has several benches that line the periphery of the playground for parents to occupy, I did not observe any interaction among the parents on the bench. This could be due to the linear placement of the benches, so it's easy to avoid eye contact. The Couch Park redesign includes benches shaped in a more concave design near the playground area. I believe this could be enough to prompt more overt social behaviour among strangers as they would be more likely to make eye contact. Besides the lack of overt behaviour on the playground benches, I would also say that more benches, or movable singular seating, would increase the population of people staying. No more than one party sat on the longer benches along the path at one time and mostly all of these were solo parties. In addition, I observed that many parents were leaning on the fence that surrounds the playground as they observed their children because the other benches were occupied. As I mentioned previously, Gehl's studies have shown that doubling the amount of seating can increase the number of people staying. If more people are staying, then there is more opportunity for occupying a space with an "other” and more opportunity for overt socializing.

\begin{tabular}{|l|l|l|l|}
\hline & Couch Street & Couch Park & Lovejoy \\
\hline Rainy Day & 3 & 5 & 12 \\
\hline Sunny Day (avg) & 14.5 & 19 & 5 \\
\hline
\end{tabular}

\footnotetext{
${ }^{15}$ People Places, pg 93
} 


\begin{tabular}{|l|l|l|l|}
\hline & $20.69 \%$ & $26.32 \%$ & $240 \%$ \\
\hline
\end{tabular}

TABLE 5. Number of parties staying, on benches during different weather patterns.

Lovejoy was successful in its retaining people on a rainy day. It does seem that, a greater percent $(77.27 \%)$ of the population used it for overt social behavior but a majority of this was due to one major group that occupied the space during a rainy day. Although most of the staying was done by this particular group, I think having the pavillion protect from the weather, encouraged a longer length of stay on the rainy day (53.5 minutes) in comparison to Couch Street and Couch Park (2.8 and 3.33 minutes respectively) in similar weather.

However, in comparison to the other two sites, Lovejoy had significantly less people staying. Part of the issue may be that the park was designed before the apartment buildings that surround it. One of the buildings has balconies for all its units and it is likely that people just observe the space from there. I also think it is due to the houseless activity in the park. Sociologist Lyn Lofland speaks of "Location socialization, ${ }^{16 "}$ where people may know a place well but because of the activity that they know happens there, they don't go. In this case, people know not to go there because of houseless group activity that occupy a majority of the benches.

If I were to exclude the one big group that stayed at Lovejoy Park on the rainy day $(-30.60 \%)$, Couch street had the highest amount of overt social behaviour (50\%). This could be due to Couch Street being an area with a lot of pedestrian traffic. A recent study shows that in June 2018 the intersection of Burnside and 10th had around 14, 623 pedestrians pass through in 12 hours. The intersection of Clay and 3rd, which is 4 blocks from the Lovejoy location, had only $4,437^{17}$. With the higher traffic and more overt activity, this supports Ghel's suggestion that "social activities occur

\footnotetext{
${ }^{16}$ Lofland, pg 102

${ }^{17}$ Downtown Clean \& Safe
} 
spontaneously, as a direct consequence of people moving about and being in the same spaces." Whyte also seems to observe similar behaviour in his study by stating that people didn't move out of the pedestrian flow when having a conversation and tended to sit in areas right off mainstream traffic. ${ }^{18}$

However its success in overt behaviour, Couch Street lacked accomodations for rainy days. In comparison to the other two locations, this space had the least amount of people staying (3 parties) and the shortest stays (2.8 minute average) on the rainy observation day. Looking at its surrounding context, this particular area of the street lacks public staying areas that protect from the elements. The only covered seated areas around were private businesses with sidewalk tables (i.e. Whole Foods and Peets Coffee).

\section{Triangulation}

All three locations seemed to have a point of interest that could be used as a triangulation device. It seemed as if children at Couch Park were a point of interest in that a lot of the people staying were watching the children (34.88\%) even if they didn't have children of their own. However, it was not sufficient to get parents staying on the benches talking. The playground itself is a form of triangulation for the children occupying that space, but it seems that parents needs something more than their children to serve as a point of interest while staying at this park. It also may be beneficial to provide smaller activities away from the nucleus of activity. For example, one lady brought her kid to the park, but instead of heading to the playground, she brought a bubble machine to entertain her son. People walking by would slow their pace to watch them, and two people even started a brief, amicable conversation with her.

\footnotetext{
${ }^{18}$ Whyte, pg 21
} 
On Couch Street, there was a street performer across the street from the benches on the two sunny days of observation. 3 parties that stayed on the benches pointed or looked in his direction while sitting on the bench. Besides this street performer, it seemed that the buildings and the city itself seemed like a point of interest, where parties would point at the surrounding buildings while conversing. Although Gehl says that flashy building designs aren't what attract people to a space, it seems that good design is still of importance for people that are staying to observe.

Lovejoy Park did not seem to have any point of interest in the times I was observing. It would be interesting to see how interactions in the space change in the summer months when Lovejoy Fountain is on since people bring their children to play and cool down from the heat.

\section{SOCIOLOGICAL ANALYSIS}

\section{Houseless}

Houseless activity was essential to the Couch Park and Lovejoy location. Houseless persons composed $32.56 \%$ and $40.91 \%$ of both locations' bench population respectively. Couch Street on the other hand only had 1 houseless person occupy a bench, $3.13 \%$ of its population.

During one of my observation times at Couch Park, there was a houseless man that fell asleep sitting up on the bench, since there were dividers that kept him from laying down. On a seperate bench during the same time, a male parent watching his child also fell asleep on the bench. People passing by stared more at the houseless man, than the parent. Lofland offers a potential reason for this. She refers to backstage behaviour, where people behave as if they were in private: "The resident colonizer may relax his behaviour a good deal, but the fact remains, he is in a public place, and if he is to retain approval for his colonization, such relaxation must be controlled." ${ }^{19}$ Thus the well kept dad

\footnotetext{
${ }^{19}$ Lofland, pg 127
} 
sitting on the bench seems innocent and in control of his backstage behaviour and is a "colonizer blessed with approval", meanwhile the houseless man oversteps the boundary of approval for some and makes people concerned because of his rugged, backstage appearance.

Although houseless loitering in an space is, unfortunately, unapproved of, I think the relation of houseless to street furniture could be a place for further research. In both the Lovejoy location and Couch Park locations houseless groups arranged themselves in a sort of huddle around the bench in order to have a conversation, where some people were sitting on the bench, some standing behind and others sitting in front of the bench. These interactions indicate that there are not enough spaces to adequately accommodate larger groups for staying. Lovejoy Park was interesting as well, because on the day that the larger group of houseless people and their friends were staying on the benches, other people seemed to avoid the space. In reality the group was only occupying two out of the six benches, but since they are all located under the pavillion, it made the space seem smaller than it actually is. This could have discouraged people outside of this pack from staying. Subtle design changes could be made in order to offer a variety of spaces for different group sizes.

\section{Solo Users}

\begin{tabular}{|l|l|l|l|l|}
\hline & Couch Street (16) & Couch Park (28) & Lovejoy Park (7) & Total \\
\hline Female & $25.00(4)$ & $35.71(10)$ & $28.57(2)$ & $31.37(16)$ \\
\hline Male & $75.00(12)$ & $64.29(18)$ & $71.43(5)$ & $68.63(35)$ \\
\hline
\end{tabular}

TABLE 6. Solo Male and Female users staying on benches.

There was a total of 51 strictly solo users ( $52.58 \%$ of total parties). Of those users $68.63 \%$ were male and $31.37 \%$ were female. Other studies indicate that women don't use a space for staying and only use it to pass through when they feel there is a male-majority staying in a space ${ }^{20}$. If interpreting

\footnotetext{
${ }^{20}$ Ortiz, et al
} 
this as an indicator of safety, we should design to allow more room for women to occupy these spaces alone. This is an area that could use further research and is certainly important if we are to design more inclusive cities.

\section{Capacity}

Another point of interest in this study is an affirmation to Whyte's comment on a place's capacity. He argues that subconsciously users in a public setting know how many people can comfortably occupy a space: "People have a nice sense of the number that is right for a place, and it is they who determine how many is too many... they go there by choice - not to escape the city but to partake of it. ${ }^{21}$ " The staying activity on benches seemed to happen in clusters. By this I mean that there were periods of time where there was no activity happening until someone "broke the silence" and stayed on a bench. This was then followed by a ballet of activity where people would come and go until there was no activity again. This seems like a way for people occupying benches to interact with other bench users and pedestrians walking by.

\section{DISCUSSION}

\section{Lack of Overt Socializing}

While covert socializing is a completely valid way of occupying public space, it seems that there is a general lack of overt socializing in these spaces. Part of this could be that these spaces seemed to lack some necessities, such as more seating for parents at Couch Park. However I believe there might be some avoidance of interaction due to just the people themselves. This is due to my observations from Couch Park, where parents don't talk to one another, and at Lovejoy where people avoid the space when there is too large of an "other."

\footnotetext{
${ }^{21}$ Whyte, pg 100
} 
Why, then, is there a greater percentage of covert socializing? In here book, sociologist Lyn Lofland offers one possible reason. She argues that the city is too overwhelming and it is for that reason that people return to a villager mindset by using methods that makes the city feel smaller. In this way, people can control the stimuli they are receiving and "create for themselves a symbolic shield of privacy." ${ }^{22}$ While this could be debated, her point of making private what is public, she argues can only be done by transforming "the character of his social psychological relationship with that space." 23 This is a habit that Whyte also observed in his studies where people tried to make public space a little slice of private space through small mannerisms like the adjusting a chair. Usually these adjustments where no more than moving the chair a couple of inches ${ }^{24}$, but in doing so it allows people to feel like that space is now theirs to inhabit.

\begin{tabular}{|l|l|l|l|l|}
\hline & Couch Street & Couch Park & Lovejoy Park & Total \\
\hline Phone & $46.88(15)$ & $41.86(18)$ & $18.18(4)$ & $38.14(37)$ \\
\hline Overt Behavior & $50.00(16)$ & $27.91(12)$ & $77.27(17)$ & $46.39(45)$ \\
\hline
\end{tabular}

TABLE 7. Phone and Overt behaviour comparison between locations

Lofland also states that another method of privatizing space is simply by not making eye contact. ${ }^{25}$ If this is true, it would make sense as to why there was a high amount of phone use in these public spaces. Malcolm McCullough provides solutions to combating this distraction by saying designers need to rethink attention and create spaces that appeal to all the senses since "nothing can be designed on the assumption that it will be noticed". ${ }^{26}$ Gehl supports this and says "the main attraction of these spaces is not just city life as such, but rather a potpourri of sensory impressions" ${ }^{27}$ Rather than

\footnotetext{
${ }^{22}$ Lofland, pg 151

${ }^{23}$ Lofland, pg 140

${ }^{24}$ Whyte, pg 36

${ }^{25}$ Lofland, pg 153

${ }^{26}$ McCullough, pg 23

${ }^{27}$ Cities for People, pg 178
} 
making flashy, strictly-visual designs to regain the attention of its users, public spaces need to be designed in a way that maybe are a palate cleanser to the visual overload we are used to. In this way people may be more willing to lift their eyes up from their screens and be more aware of whatever space they find themselves in.

\section{Weather}

As mentioned previously, bench use is minimal on rainy day. On these days, people only stopped at a bench to adjust any baggage they may be carrying or for a quick smoke when the rain subsided for the uncovered, Couch Street and Couch Park locations. Seeing as how Portland receives a majority of its rain in eight out of the twelve months of the year ${ }^{28}$, it is necessary to design public staying spaces that are more weather friendly. The pavilion at Lovejoy park played an important role in the locations rainy day us. Aside from that location, the only other major outdoor public spaces with rain coverage in downtown Portland is Directors Park and areas under the bridges on Waterfront Park. There is a great opportunity to not only design for accommodating the weather but using weather as a triangulation device. As Gehl mentions "weather is a favorite topic of conversation everywhere," ${ }^{29}$ as it is one of the first topics that come to mind when commencing small talk. With how much it rains in Portland, it would be interesting to see outdoor public space design embrace it as a point of interest. Whether it be to meet a necessity or a whim, designing for rain would make the city more habitable and encourage overt social behaviour during these eight months of the year.

\section{Further Research}

Due to the complexity and ephemerality of city life, there is always room for more research of public life. If I were to recreate this specific study again, it would be beneficial to study these spaces

\footnotetext{
${ }^{28}$ Oregon Live

${ }^{29}$ Cities for People, pg 168
} 
during other seasons and make it a yearly study. Also, as one person, the importance of working in a group became evident very quickly since there was a lot of other factors I couldn't observe such such as how many people are walking by versus staying. Conducting interviews would also be beneficial to better understanding a person's reason for engaging in covert or overt social behaviour.

For further research it would also be useful to observe areas that are more specific to certain groups such as just park, or just areas outside business offices or clubs or wherever else a lot of people gather, so that designs could be more function specific. If given the resources and manpower, I would be interested in studying universities and their staying areas. Since universities are a place with many flowing ideas it would be beneficial to see how the theirstaying areas can be better designed to create dialogue across disciplines.

Although there seemed to be a correlation between lack of over socializing and higher phone use, it's unreasonable to wish away technology or ignore it as a very real object of attention. Instead designers should keep it as a design consideration when designing social spaces, and look for room for collaboration. For example, Niantic, the creators of Pokemon Go, joined the city of Charlotte, North Caroline's Open Streets event where the city included major PokeStops and Gyms along the event route to encourage more participation. ${ }^{30}$

\section{CONCLUSION}

While a city and its components are very complex and ultimately beyond the scope of studying down to a complete science, I would like to mimic Whyte's feelings when it comes to improving the social nature of public spaces.

"I am not, heaven forfend, going on to argue for places of maximum gregariousness, social directors for plazas. Anomie would be preferable. What I'm suggesting, simply, is that we make places friendlier. We know how. In both the design and management of spaces, there are

\footnotetext{
${ }^{30}$ Brasuell, James
} 
many ways to make it much easier for people to mingle and meet. It would be no bad idea to move more in this direction." 31

If the pattern of covert to overt social behaviour I observed in Couch Park, Couch Street and Lovejoy Park is true for other public spaces, more needs to be done in order to move towards creating social public spaces. Even if people aren't socializing because of a political atmosphere, which is outside of the scope of design alone, I believe that Gehl, Whyte, and others' work in public life studies and design have shown that places can be transformed with careful observation and good redesign. The first step being meeting the basic necessities for all peoples. That includes designing for spaces that allow more minorities (women, ADA beneficiaries, people of color, etc.) to feel safe and comfortable with staying in a space. After these necessities are met, designers need to think like a host and design in a way that will make guests mingle. This could be in being more bold in triangulating methods or looking for innovative methods such as collaborations with technology. Whatever the methods, they should be more intentional in socializing public space.

${ }^{31}$ Whyte, pg 98 


\section{BIBLIOGRAPHY}

Arieff, Allison (2017). “Opinion | Designing a More Inclusive City.” The New York Times, October 20, 2017, sec. Opinion. https://www.nytimes.com/2017/10/20/opinion/designing-inclusive-cities.html.

Brasuell, James (2017). "Pokemon Go to expand its Reach in the Community.” Planetizen, May 11, 2017. https://www.planetizen.com/node/92704/pok\%C3\%A9mon-go-expand-its-reach-communit y

Crawford, Amy. n.d. “The 'War on Sitting' Has a New Front.” Accessed November 2, 2017. https://www.citylab.com/design/2017/10/cities-take-both-sides-in-the-war-on-sitting/54264 $\underline{3 /}$.

Downtown Clean \& Safe. "June 2018 Pedestrian Count Results and Comparables” Gehl, Jan (1980). Life Between Buildings. New York: Van Nostrand Reinhold Company, Inc. Gehl, Jan (2010). Cities for People. Washington, D.C.: Island Press.

Gehl, Jan and Birgitte Svarre (2013). How to Study Public Life. Washington, D.C.: Island Press. Halprin Landscape Conservancy

Halprin, Lawrence (1963). Cities. New York: Reinhold Publishing Corporation.

Lofland, Lyn H. (1973). A World of Strangers. New York: Basic Books, Inc.

Marcus, Clare Cooper and Carolyn Francis (1998). People Place: Design Guidelines for Urban Open Space. New York: Van Nostrand Reinhold.

McCullough, Malcolm (2013). Ambient Commons: Attention in the Age of Embodied Information. Cambridge: The MIT Press. 
Morris, Lydia. 2015. "Plaques Installed on Benches Banning ‘old, Ugly and Poor’ from Sitting Down.” Mirror. October 19, 2015. http://www.mirror.co.uk/news/uk-news/pranksters-create-comedy-plaques-high-6658983.

Ortiz, Anna, Maria Dolores Garcia-Ramon and Maria Prats. 2004. “Women’s use of public space and sense of place in the Raval (Barcelona)", GeoJournal 61: 219-227.

Dame, T. and A. Grant (2001). “Safe Public Spaces for Women and Girls” Kelowna Planning for Safer Communities Workshop Report. Cowichan Valley Safer Futures Program, Canada: pg. 17.

Tomlinson, Stuart, 2014. "Oregon rainy season: Wet, wild and sometimes wonderful, defining the region.” The Oregonian/Oregon Live, October 2014.

https://www.oregonlive.com/weather/index.ssf/2014/10/oregon_rainy_season_its_wet_wi.h $\underline{\mathrm{tml}}$

Valentine, G. (1990). Women's Fear and the Design of Public Space. Built Environment (1978-), $16(4)$ 288-303.

Whyte, William H. (1980). The Social Life of Small Urban Spaces. Washington, D.C.: The Conservation Foundation. 